\title{
Hubungan antara Persepsi Remaja tentang Penggunaan Alat Ortodontik Cekat dan Minat terhadap Perawatan Maloklusi (Penelitian pada Pelajar SMAK "X” Bandung)
}

\author{
The Relationship between the Perception of Late \\ Adolescence Using Fixed Orthodontic Appliance and \\ Interest towards Ofmalocclusion Treatment \\ (Experiment was held on students of SMAK " $X$ " \\ Bandung)
}

\author{
Jolanda $^{1}$, Cindy Maria ${ }^{2}$, Marlin Himawati ${ }^{3}$ \\ ${ }^{1}$ Mahasiswa Program Pendidikan Profesi Dokter Gigi, Fakultas \\ Kedokteran Gigi, Universitas Kristen Maranatha, Bandung \\ 2 Dosen Fakultas Psikologi, Universitas Kristen Maranatha, \\ Bandung \\ ${ }^{3}$ Bagian Ortodonsia, RSGM Universitas Kristen Maranatha, \\ Bandung
}

\begin{abstract}
Abstrak
Abstrak: Persepsi adalah proses mengorganisir dan menginterpretasi informasi sensori untuk memberikan makna. Persepsi tentang penggunaan alat ortodontik cekat dapat dilihat dari aspek estetik dan aspek fungsional. Bagi remaja, salah satu hal yang paling penting adalah penampilan fisik. Penampilan fisik terutama dapat dilihat dari penampilan wajah, tidak terlepas dari penampilan gigi dan mulut. Tujuan penelitian adalah untuk mengetahui hubungan antara persepsi remaja tentang penggunaan alat ortodontik cekat dan minat terhadap perawatan maloklusi pelajar SMAK "X" Bandung. Jenis penelitian yang digunakan adalah analitik dengan rancangan penelitian cross-sectional dan teknik pengambilan sampel yang digunakan adalah purposive sampling. Besar sampel yang memenuhi kriteria inklusi dan eksklusi sebanyak 41 orang. Tabulasi silang antara persepsi dan minat memperlihatkan minat responden paling banyak dalam kategori minat sedang baik persepsi dari aspek estetik maupun aspek fungsional. Analisis data dari penelitian menggunakan chi-square test dengan $\alpha$ $=0,05$. Hubungan antara persepsi remaja tentang penggunaan alat ortodontik cekat dan minat terhadap perawatan maloklusi tidak signifikan dengan $p=0,456$.
\end{abstract}

Kata kunci: persepsi, minat, remaja, alat ortodontik cekat, maloklusi.

\footnotetext{
Abstract

Abstract: Perception is the process of organizing and interpreting sensory information to provide meaning. Perceptions about the use of fixed orthodontic appliance can be seen from aesthetic and functional aspects. For late adolescence, one of the most important thing is the physical appearance. Appearance can be seen mostly from the face, which is related to the teeth and mouth. The purpose of this study is to determine the relationship between the perception of late adolescence using fixed orthodontic appliance and interest towards of malocclusion treatment in SMAK " $X$ " students in Bandung. This research was an analytic cross-sectional study design and the sampling technique used a purposive sampling. The amount of sample which met the inclusion and exclusion criteria was 41 students. Cross-tabulation between perception and interests showed that the most interests of the respondent was seen in the moderate category in perception of both functional and aesthetic aspects. The data was analyzed using chi-square test with $\alpha=0,05$. The relationship between the perception of late adolescence using fixed orthodontic appliance and interest towards of malocclusion treatment did not show a significant result with $p=0,456$.
} 
Jolanda, Cindy Maria, Marlin Himawati Hubungan antara Persepsi Remaja tentang Penggunaan Alat Ortodontik Cekat dan Minat terhadap Perawatan Maloklusi (Penelitian pada Pelajar SMAK "X" Bandung)

Key words: perception, interest, adolescent, fixed orthodontic appliance, malocclusion

\section{PENDAHULUAN}

Salah satu hal yang paling penting bagi remaja adalah penampilan fisik. Penampilan fisik terutama dapat dilihat dari penampilan wajah, tidak terlepas dari penampilan gigi dan mulut. ${ }^{1}$ Remaja menyadari bahwa kesan pertama sangat dipengaruhi oleh penampilan. ${ }^{2}$ Pada masa pubertas, remaja menjadi sangat memperhatikan tubuh. ${ }^{3,4}$ Menurut Witherington, remaja usia 15 sampai 18 tahun paling banyak berada di tingkat Sekolah Menengah Atas (SMA) yang merupakan saat eksplorasi diri dan memiliki minat yang sangat tinggi, ${ }^{3,5}$

Penghayatan remaja mengenai penampilan wajah memengaruhi perkembangan psikologis dari masa anak hingga dewasa. ${ }^{6}$ Penampilan dari wajah terbukti digunakan sebagai pedoman untuk menyimpulkan berbagai karakteristik mengenai seseorang, termasuk kepribadian, integritas, kompetensi sosial, kompetensi intelektual, dan kesehatan mental yang menunjukan hasil hubungan interpersonal yang lebih baik dan kepercayaan diri yang lebih tinggi. ${ }^{7,8}$ Salah satu komponen yang paling penting dari penampilan wajah adalah gigi dan mulut. ${ }^{8}$ Menurut penelitian Shaw et al., disimpulkan bahwa individu cenderung menghina penampilan gigi yang buruk daripada penampilan yang lain, seperti pakaian, berat badan, telinga, dan lainlain. ${ }^{9}$ Individu yang mempunyai susunan gigi yang kurang baik memerlukan penggunaan alat ortodontik cekat sebagai perawatan terhadap maloklusi. ${ }^{10}$

Persepsi adalah proses mengorganisir dan menginterpretasi informasi sensori untuk memberika makna. ${ }^{4}$ Persepsi tentang penggunaan alat ortodontik cekat dapat dilihat dari aspek estetik dan aspek fungsional. Persepsi tentang penggunaan alat ortodontik cekat dari aspek estetik biasanya merupakan motivasi utama individu terutama remaja dalam mencari perawatan maloklusi. ${ }^{8}$ Sebagian besar minat terhadap perawatan maloklusi pada kalangan remaja didorong oleh kepedulian pribadi mengenai penampilan yaitu dari aspek estetik. ${ }^{11}$ Minat adalah suatu keadaan ketika seseorang mempunyai perhatian terhadap sesuatu dan disertai keinginan untuk mengetahui dan mempelajari maupun membuktikan lebih lanjut. ${ }^{12}$ Menurut Baldwin, sebanyak $80 \%$ individu yang menerima perawatan ortodontik ternyata mengabaikan pertimbangan dari aspek fungsional, namun perawatan ortodontik mempunyai tujuan lainnya seperti meningkatkan kesehatan dari aspek fungsional, ${ }^{13,14}$ maka peneliti tertarik untuk melakukan penelitian mengenai hubungan antara persepsi tentang penggunaan alat ortodontik cekat dan minat terhadap perawatan maloklusi pelajar SMAK "X"Bandung.

\section{METODE PENELITIAN}

Jenis penelitian yang digunakan adalah analitik. Penelitian dilaksanakan pada bulan Mei 2015 di SMAK "X" Bandung. Populasi pada penelitian yaitu semua pelajar SMAK "X" Bandung yang belum pernah menggunakan alat ortodontik cekat berjumlah 41 orang. Metode pengambilan sampel menggunakan teknik purposive sampling. Kriteria inklusi untuk penelitian yaitu usia remaja (15-18 tahun) dan bersedia menjadi subjek penelitian yang dibuktikan dengan kesediaan untuk mengisi surat persetujuan sebagai subjek penelitian. Kriteria eksklusi yaitu pelajar yang sedang atau telah menjalani perawatan ortodontik cekat.

Pada instrumen penelitian, kuisioner untuk mengukur variabel persepsi berjumlah dua puluh pernyataan yang dibagi menjadi dua aspek, yaitu aspek estetik dan aspek fungsional dengan 
masing-masing aspek terdiri dari sepuluh pernyataan yang disusun oleh peneliti berdasarkan teori Proffit ${ }^{10}$ (Tabel 1). Kuisioner untuk mengukur minat terdiri dari sepuluh pernyataan yang disusun oleh peneliti berdasarkan teori Walgito ${ }^{12}$ (Tabel 2). Kuisioner disusun berdasarkan skala Likert dengan pilihan jawaban sebanyak empat, mulai dari sangat sesuai, sesuai, tidak sesuai, dan sangat tidak sesuai.
Pernyataan-pernyataan terdiri dari item positif (favorable) dan negatif (unfavorable). Skor terendah yang diperoleh untuk variabel persepsi adalah 10 dan skor tertinggi adalah 40 untuk tiap aspek. Pada variabel minat dibagi menjadi tiga kategori, yaitu rendah, sedang, dan tinggi. Interval skor untuk kategori rendah adalah 10-20, kategori sedang 21-30, dan kategori tinggi 31-40.

Tabel 1. Alat Ukur Persepsi ${ }^{10}$

\begin{tabular}{|c|c|c|c|}
\hline Aspek & Indikator & Item & $\begin{array}{l}\text { Favorable I } \\
\text { Unfavorable }\end{array}$ \\
\hline \multirow[t]{10}{*}{ Estetik } & \multirow[t]{2}{*}{$\begin{array}{l}\text { Perbaikan } \\
\text { deviasi } \\
\text { dentofacial }\end{array}$} & $\begin{array}{l}\text { Penggunaan alat ortodontik cekat bagi } \\
\text { saya dapat memperbaiki tampilan yang } \\
\text { kurang menarik pada gigi, mulut, dan } \\
\text { wajah. }\end{array}$ & Favorable \\
\hline & & $\begin{array}{l}\text { Penggunaan alat ortodontik cekat } \\
\text { membuat saya mendapat julukan yang } \\
\text { menghina gigi dan mulut saya. }\end{array}$ & Unfavorable \\
\hline & \multirow[t]{4}{*}{$\begin{array}{l}\text { Ketertarikan } \\
\text { sosial }\end{array}$} & $\begin{array}{l}\text { Makna penggunaan alat ortodontik cekat } \\
\text { bagi saya dapat menurunkan kualitas } \\
\text { kehidupan sosial. }\end{array}$ & Unfavorable \\
\hline & & $\begin{array}{l}\text { Saya menghayati penggunaan alat } \\
\text { ortodontik cekat dapat memperbaiki } \\
\text { hubungan interpersonal saya. }\end{array}$ & Favorable \\
\hline & & $\begin{array}{l}\text { Penggunaan alat ortodontik cekat bagi } \\
\text { saya dapat memperbaiki kelas sosial di } \\
\text { lingkungan. }\end{array}$ & Favorable \\
\hline & & $\begin{array}{l}\text { Saya menghayati penggunaan alat } \\
\text { ortodontik cekat dapat mengubah } \\
\text { pandangan negatif orang terhadap saya. }\end{array}$ & Favorable \\
\hline & \multirow[t]{4}{*}{$\begin{array}{l}\text { Kepercayaan } \\
\text { diri }\end{array}$} & $\begin{array}{l}\text { Penggunaan alat ortodontik cekat } \\
\text { membuat kepercayaan diri saya terhadap } \\
\text { gigi dan mulut meningkat. }\end{array}$ & Favorable \\
\hline & & $\begin{array}{l}\text { Penggunaan alat ortodontik cekat bagi } \\
\text { saya dapat menurunkan rasa percaya } \\
\text { diri. }\end{array}$ & Unfavorable \\
\hline & & $\begin{array}{l}\text { Saya menghayati penggunaan alat } \\
\text { ortodontik cekat dapat meningkatkan } \\
\text { popularitas saya di lingkungan. }\end{array}$ & Favorable \\
\hline & & $\begin{array}{l}\text { Makna penggunaan alat ortodontik cekat } \\
\text { bagi saya dapat meningkatkan rasa puas } \\
\text { terhadap keadaan gigi dan mulut. }\end{array}$ & Favorable \\
\hline Fungsional & Pergerakan & Penggunaan alat ortodontik cekat bagi & Unfavorable \\
\hline
\end{tabular}


Jolanda, Cindy Maria, Marlin Himawati | Hubungan antara Persepsi Remaja tentang Penggunaan Alat Ortodontik Cekat dan Minat terhadap Perawatan Maloklusi (Penelitian pada Pelajar SMAK "X" Bandung)

\begin{tabular}{|c|c|c|}
\hline \multirow{2}{*}{$\begin{array}{l}\text { rahang } \\
\text { normal } \\
\text { a. Koordinasi } \\
\text { otot baik } \\
\text { b. Tidak ada } \\
\text { rasa nyeri }\end{array}$} & \multicolumn{2}{|l|}{$\begin{array}{l}\text { saya dapat meningkatkan masalah } \\
\text { pergerakan otot saat menggerakkan } \\
\text { rahang karena susunan gigi yang kurang } \\
\text { beraturan. }\end{array}$} \\
\hline & $\begin{array}{l}\text { Saya menghayati penggunaan alat } \\
\text { ortodontik cekat dapat mengurangi rasa } \\
\text { sakit saat menggerakkan rahang karena } \\
\text { susunan gigi yang kurang beraturan. }\end{array}$ & Favorable \\
\hline TMJ normal & $\begin{array}{l}\text { Makna penggunaan alat ortodontik cekat } \\
\text { bagi saya dapat memperbaiki kelainan } \\
\text { pada sendi rahang yang mengganggu } \\
\text { aktivitas karena susunan gigi yang } \\
\text { kurang beraturan. }\end{array}$ & Favorable \\
\hline $\begin{array}{l}\text { Fungsi } \\
\text { pengunyahan } \\
\text { baik }\end{array}$ & $\begin{array}{l}\text { Penggunaan alat ortodontik cekat bagi } \\
\text { saya dapat memperburuk masalah } \\
\text { pengunyahan karena susunan gigi yang } \\
\text { kurang beraturan. }\end{array}$ & Unfavorable \\
\hline $\begin{array}{l}\text { Fungsi } \\
\text { penelanan } \\
\text { baik }\end{array}$ & $\begin{array}{l}\text { Makna penggunaan alat ortodontik cekat } \\
\text { bagi saya dapat memperbaiki masalah } \\
\text { penelanan karena susunan gigi yang } \\
\text { kurang beraturan. }\end{array}$ & Favorable \\
\hline $\begin{array}{l}\text { Fungsi bicara } \\
\text { baik }\end{array}$ & $\begin{array}{l}\text { Saya menghayati penggunaan alat } \\
\text { ortodontik cekat dapat memperbaiki } \\
\text { masalah pada fungsi bicara karena } \\
\text { susunan gigi yang kurang beraturan. }\end{array}$ & Favorable \\
\hline $\begin{array}{l}\text { Pencegahan } \\
\text { terhadap } \\
\text { trauma }\end{array}$ & $\begin{array}{l}\text { Makna penggunaan alat ortodontik cekat } \\
\text { bagi saya dapat mengurangi } \\
\text { kemungkinan terjadinya benturan pada } \\
\text { gigi yang dapat menyebabkan kerusakan } \\
\text { yang lebih parah. }\end{array}$ & Favorable \\
\hline $\begin{array}{l}\text { Pencegahan } \\
\text { terhadap } \\
\text { karies }\end{array}$ & $\begin{array}{l}\text { Penggunaan alat ortodontik cekat bagi } \\
\text { saya dapat mengurangi kemungkinan } \\
\text { terjadinya gigi berlubang karena } \\
\text { susunan gigi yang kurang beraturan. }\end{array}$ & Favorable \\
\hline $\begin{array}{l}\text { Pencegahan } \\
\text { terhadap } \\
\text { gingivitis }\end{array}$ & $\begin{array}{l}\text { Makna penggunaan alat ortodontik cekat } \\
\text { bagi saya dapat meningkatkan } \\
\text { kemungkinan terjadinya gusi berdarah } \\
\text { karena susunan gigi yang kurang } \\
\text { beraturan. }\end{array}$ & Unfavorable \\
\hline $\begin{array}{l}\text { Pencegahan } \\
\text { terhadap } \\
\text { penyakit } \\
\text { periodontal }\end{array}$ & $\begin{array}{l}\text { Saya menghayati penggunaan alat } \\
\text { ortodontik cekat dapat mengurangi } \\
\text { kemungkinan terjadinya kegoyangan } \\
\text { gigi karena susunan gigi yang kurang } \\
\text { beraturan. }\end{array}$ & Favorable \\
\hline
\end{tabular}


Tabel 2. Alat Ukur Minat ${ }^{12}$

\begin{tabular}{|c|c|c|}
\hline Indikator & Item & $\begin{array}{l}\text { Favorable / } \\
\text { Unfavorable }\end{array}$ \\
\hline \multirow[t]{2}{*}{ Perhatian } & $\begin{array}{l}\text { Saya sering memperhatikan teman saya yang } \\
\text { menggunakan alat ortodontik cekat. }\end{array}$ & Favorable \\
\hline & $\begin{array}{l}\text { Saya acuh tak acuh terhadap alat ortodontik cekat } \\
\text { yang digunakan oleh teman saya. }\end{array}$ & Unfavorable \\
\hline \multirow[t]{3}{*}{$\begin{array}{l}\text { Keinginan } \\
\text { mengetahui }\end{array}$} & $\begin{array}{l}\text { Saya ingin tahu lebih banyak tentang alat } \\
\text { ortodontik cekat. }\end{array}$ & Favorable \\
\hline & $\begin{array}{l}\text { Saya mencari tahu informasi mengenai alat } \\
\text { ortodontik cekat. }\end{array}$ & Favorable \\
\hline & $\begin{array}{l}\text { Saya jarang bertanya mengenai alat ortodontik } \\
\text { cekat pada teman yang menggunakan. }\end{array}$ & Unfavorable \\
\hline \multirow[t]{2}{*}{$\begin{array}{l}\text { Keinginan } \\
\text { mempelajari }\end{array}$} & $\begin{array}{l}\text { Saya berusaha untuk memahami manfaat-manfaat } \\
\text { alat ortodontik cekat. }\end{array}$ & Favorable \\
\hline & $\begin{array}{l}\text { Saya tidak tertarik untuk memahami hal-hal yang } \\
\text { berhubungan dengan alat ortodontik cekat. }\end{array}$ & Unfavorable \\
\hline \multirow{3}{*}{$\begin{array}{l}\text { Keinginan } \\
\text { membuktikan } \\
\text { lebih lanjut }\end{array}$} & $\begin{array}{l}\text { Saya tidak tertarik untuk melakukan perawatan } \\
\text { dengan alat ortodontik cekat. }\end{array}$ & Unfavorable \\
\hline & $\begin{array}{l}\text { Saya berusaha mencari perawatan dengan alat } \\
\text { ortodontik cekat. }\end{array}$ & Favorable \\
\hline & Saya ingin menggunakan alat ortodontik cekat. & Favorable \\
\hline
\end{tabular}

Prosedur pengambilan data dilakukan dengan cara membuat rumusan pernyataan dalam kuisioner dan melakukan uji validitas dan reliabilitas kuisioner. Uji validitas pada penelitian menggunakan korelasi Product Moment (Pearson) dan Cronbach Alpha untuk menghitung koefisien reliabilitas. Kuisioner yang telah diuji validitas dan reliabilitas digunakan pada sejumlah sampel yang telah ditentukan. Pengisian kuisoner kurang lebih dilakukan selama 25 menit. Data yang diperoleh, diolah dan dianalisis berdasarkan distribusi frekuensi dalam bentuk tabel dan grafik. Pengujian hipotesis dengan menggunakan chi-square test dengan kriteria pengujian jika nilai $p \leq$ 0,05 maka $\mathrm{H}_{1}$ diterima, sedangkan jika nilai $p>0,05$ maka $\mathrm{H}_{1}$ ditolak. 
Jolanda, Cindy Maria, Marlin Himawati | Hubungan antara Persepsi Remaja tentang Penggunaan Alat Ortodontik Cekat dan Minat terhadap Perawatan Maloklusi (Penelitian pada Pelajar SMAK "X" Bandung)

\section{HASIL PENELITIAN}

Tabel 3. Distribusi Frekuensi Persepsi tentang Penggunaan Alat Ortodontik Cekat dan Minat terhadap Perawatan Maloklusi

\begin{tabular}{llllll}
\hline & & \multicolumn{3}{l}{ Kategori minat } & \\
& & Rendah & Sedang & Tinggi & Total \\
\hline Persepsi & Estetik & $2(12 \%)$ & $14(82 \%)$ & $1(6 \%)$ & $17(100 \%)$ \\
& Fungsional & $6(33 \%)$ & $12(67 \%)$ & 0 & $18(100 \%)$ \\
& Fungsional dan & $2(33 \%)$ & $4(67 \%)$ & 0 & $6(100 \%)$ \\
estetik & & & & \\
\hline & Total & 10 & 30 & 1 & 41 \\
\hline
\end{tabular}

Berdasarkan hasil distribusi frekuensi persepsi tentang penggunaan alat ortodontik cekat dan minat terhadap perawatan maloklusi, (Tabel 3) diketahui sebanyak $2 \%$ responden yang termasuk kategori minat rendah dengan persepsi estetik, $82 \%$ responden yang termasuk kategori minat sedang dengan persepsi estetik, dan $6 \%$ responden termasuk kategori minat tinggi dengan persepsi estetik. Sedangkan untuk persepsi fungsional, sebanyak 33\% responden yang termasuk kategori minat rendah, $67 \%$ responden yang termasuk kategori minat sedang, dan tidak ada responden yang termasuk dalam kategori minat tinggi. Untuk persepsi estetik dan fungsional sebanyak $33 \%$ responden termasuk kategori minat rendah, $67 \%$ responden termasuk kategori minat sedang, dan tidak ada responden yang termasuk kategori tingkat tinggi.

Analisis data diuji dengan menggunakan chi-square test dengan derajat kemaknaan $\alpha=0,05$. Hasil analisis statistik menunjukan bahwa nilai $p$ 0,456 maka $\mathrm{H}_{1}$ ditolak, kesimpulan $\mathrm{H}_{1}$ ditolak, yang artinya tidak terdapat hubungan antara persepsi tentang penggunaan alat ortodontik cekat dan minat terhadap perawatan maloklusi (Tabel 4) 
Tabel 4. Hubungan antara Persepsi tentang Penggunaan Alat Ortodontik Cekat dan Minat terhadap Perawatan Maloklusi

\begin{tabular}{lc}
\hline \multicolumn{1}{c}{ Variabel Penelitian } & Nilai $p$ \\
\hline $\begin{array}{l}\text { Hubungan antara persepsi tentang penggunaan alat } \\
\text { ortodontik cekat dan minat terhadap perawatan } \\
\text { maloklusi }\end{array}$ & 0,456 \\
\hline
\end{tabular}

\section{DISKUSI}

Hasil penelitian yang dilakukan pada seluruh subjek yang terdiri dari 41 pelajar SMAK " $X$ " Bandung menunjukan bahwa tidak terdapat hubungan antara persepsi tentang penggunaan alat ortodontik cekat dan minat terhadap perawatan maloklusi pada pelajar SMAK "X" Bandung. Subjek penelitian yang memiliki persepsi tentang penggunaan alat ortodontik cekat dari aspek estetik dan persepsi tentang penggunaan alat ortodontik cekat dari aspek fungsional paling banyak dalam kategori minat sedang terhadap perawatan maloklusi, yang berarti pelajar SMAK " $X$ " Bandung mempunyai cukup perhatian terhadap penggunaan alat ortodontik cekat dan memiliki keinginan yang cukup untuk mengetahui dan mempelajari maupun membuktikan lebih lanjut perawatan terhadap maloklusi.

Menurut Sujanto, minat dapat dipengaruhi oleh beberapa faktor, diantaranya pengetahuan, pengamatan, tanggapan, persepsi, dan sikap. Persepsi yang diterima melalui alat indera akan diolah, dinilai dan diinterpretasikan dalam otak sebagai suatu informasi. Jika dari proses penilaian dan penginterpretasian menghasilkan penilaian yang positif maka penilaian akan berjalan terus menjadi hal yang menarik dan disenangi sehingga menjadi informasi yang menetap sehingga menjadi sesuatu yang diminati. Sebaliknya, jika proses penilaian dan penginterpretasian menghasilkan penilaian yang negatif, maka penilaian akan berjalan terus menjadi hal yang tidak menarik sehingga informasi akan diabaikan karena tidak diminati. ${ }^{15}$ Pengetahuan, pengamatan, tanggapan, dan sikap merupakan faktor lain yang memengaruhi minat sehingga dapat memengaruhi hasil penelitian yang dilakukan. Pengetahuan mengenai manfaat penggunaan alat ortodontik cekat dapat memengaruhi minat responden terhadap perawatan maloklusi. Pengetahuan yang kurang mengenai manfaat penggunaan alat ortodontik cekat menyebabkan minat yang rendah terhadap perawatan maloklusi. Pengamatan, tanggapan, dan sikap yang negatif terhadap penggunaan alat ortodontik cekat dapat memengaruhi minat responden untuk melakukan perawatan maloklusi sehingga responden kurang mempunyai perhatian terhadap penggunaan alat ortodontik cekat dan kurang memiliki keinginan untuk mengetahui dan mempelajari maupun membuktikan lebih lanjut perawatan terhadap maloklusi.

Tingkat keparahan maloklusi pada subjek penelitian sebagai variabel pengganggu juga dapat memengaruhi hasil penelitian karena tidak semua subjek penelitian memiliki tingkat keparahan yang sama. Tingkat keparahan maloklusi pada subjek penelitian yang berbeda-beda menyebabkan minat terhadap perawatan maloklusi yang berbeda juga, sesuai dari kebutuhan akan perawatan maloklusi dari subjek penelitian.

\section{SIMPULAN}

Simpulan pada penelitian yaitu tidak terdapat hubungan antara persepsi tentang penggunaan alat ortodontik cekat dan minat terhadap perawatan maloklusi pada pelajar SMAK "X” Bandung. 
Jolanda, Cindy Maria, Marlin Himawati Hubungan antara Persepsi Remaja tentang Penggunaan Alat Ortodontik Cekat dan Minat terhadap Perawatan Maloklusi (Penelitian pada Pelajar SMAK "X" Bandung

\section{DAFTAR PUSTAKA}

1. Bishara SE. Textbook of Orthodontics. Philadelphia: W.B. Saunders Company; 2001.

2. Hurlock EB. Adolescent Development. $5^{\text {th }}$ Ed. New York: Mcgraw-Hill Book Co; 1980.

3. Santrok JW. Perkembangan Remaja. Edisi Keenam. Jakarta: Penerbit Erlangga; 2003.

4. King L. Psikologi Umum Sebuah Pandangan Apresiatif. Jakarta: McGraw Hill Education and Salemba Empat; 2010.

5. Sobur A. Psikologi Umum dalam Lintasan Sejarah. Bandung: CV Pustaka Setia; 2013.

6. Ukra A, Bennani F, Farella M. Psychological Aspects of Orthodontics in Clinical Practice. Part two: General Psychological Wellbeing. Elsevier. 2012; 3: 6977.

7. Khan M, Fida M. Assessment of Psychosocial Impact of Dental Aesthetics. Journal of the College of Physicians and Surgeons Pakistan. 2008; 18(9): 559-564.

8. Jeremiah HG, Bister D, Newton JT. Social Perceptions of Adults Wearing Orthodontic Appliances: a Cross-Sectional Study. European Journal of Orthodontics. 2011; 33: 476-482.

9. Shaw WC, Meek SC, Jones DS. Nicknames, Teasing Harassment and the Salience of Dental Features among School Children. British Journal of Orthodontics; 1980: 7: 75-80.

10. Proffit WR, Fields HW, Sarver DM. Contemporary Orthodontics. $4^{\text {th }} \quad$ ed. Philadelphia: Mosby Elsevier; 2007.

11. Moura C, Cavalcanti AL, Gusmao ES, Soares RSC, Moura FTC, Santillo PMH. Negative Self-
Perception of Smile Associated With Malocclusions Among Brazilian Adolescents. European Journal of Orthodontics. 2013; 35: 483-490.

12. Wicaksono HY. Kreativitas dalam Pembelajaran Musik. 2009; 28(1).

13. Livas C, Delli K. Subjective and Objective Perception of Orthodontic Treatment Need: A Systematic Review. European Journal of Orthodontics. 2012; 1-7.

14. Fawzan AA. Reasons for seeking orthodontic treatment in Qassim region: a Pilot Study. International Dental Journal of Students Research. 2013; 1(3): 58-62.

15. Ardi M, Aryani L. Hubungan Antara Persepsi Terhadap Organisasi Dengan Minat Berorganisasi Pada Mahasiswa Fakultas Psikologi UIN SUSKA. Fakultas Psikologi UIN Sultan Syarif Kasim Riau. 2011; 153-163. 